\title{
Reforms and collective action in a clientelist party system: Greece during the Mitsotakis administration (1990-1993)*
}

\author{
Aris Trantidis
}

ABSTRACT: Economic reforms face a collective action problem: they trigger the reaction of groups that expect significant losses, while the anticipated gains are often dispersed across the population and too uncertain to animate strong popular support. This pattern may exhibit different characteristics in a clientelist economy where the affected groups are client groups under the protection of political parties. The reform agenda of the Mitsotakis government in Greece (1990-1993) illustrates that the collective action problem affects primarily the internal structure of the clientelist parties and thereby their capacity for political mobilisation. Reforms that depart from the established political equilibrium on economic policy will undermine the internal cohesion of the government party and will offer the opposition party the opportunity to strengthen its own unity and political mobilisation capacity.

* This is a draft earlier version of the eponymous article, published in the Journal of South European Society and Politics, 2014, Volume 19, Issue 2, pp. 215-243.

Key words: economic reforms, clientelism, political cost, collective action, crisis, Greece

Interest groups compete and lobby around the allocation of the benefits and costs of reforms initiated by the government (Alesina and Drazen 1991; Geddes 1994; Heller, Keefer and McCubbins, 1998; Schamis 1999). These groups often act as veto players effectively delaying or blocking reform initiatives (Haggard 2000:28; Tsebelis 2002). Depending on the institutional setting, the government may enjoy a degree of autonomy from group pressures and some room for manoeuvre around the options of co-optation, re-alignment, compromise and compensation (C.f. Evans 1992; Waterbury 1992). The political and economic links that have developed between the government and social groups determine the degree of autonomy of each actor from one another as well as their bargaining power. In that perspective, preferences and, ultimately, choices over economic policy in a given economic structure can be better understood in light of the dominant pattern by which political power regulates economic activity and allocates economic resources.

A clientelist economy is a distinct type of economic structure in which politicians and political parties reserve a great part of economic resources and opportunities for their supporters. The practice involves the regular exchange of benefits and develops into a strategic tool by which political parties organise their campaign infrastructure and 
coordinate their activists (C.f. Zuckerman 1979; Chubb 1982; Ware 1992, 1996; Mayhew 1986). Clientelist transfers serve as incentives for the recruitment of supporters to take an active part in the party's campaign. In that way, clientelism serves as a solution to a collective action problem of the type described by Mancur Olson (1971) this time concerning the mobilisation capacity of political parties. The party becomes the host organisation for the client groups which, in their turn, contribute to the party's capacity for political mobilisation. These groups develop permanent ties with their host party and gain stable access to selective benefits available within or around the public sector. Consequently, they act like any other rent-seeking group (Stigler 1971; Krueger 1974; Buchanan, Tollisson and Tullock 1980; Becker 1983 and 1985; Tullock, 1993 and 2005), and can become powerful and well-coordinated players that may considerably constrain government autonomy (C.f. Callaghy 1990; Evans, 1992; Waterbury 1992; Haggard, Cooper and Moon 1993).

Compared to typical rent-seeking groups, however, client groups are integral or at least proximate to political parties. Rent-seeking in a clientelist party system is primarily embedded within party structures. The political party is not simply the recipient of the demands of interest groups but, more importantly, it becomes the accommodating arena for these rent-extracting actors. This reduces the cost of lobbying and strengthens the degree of party commitment to clientelist demands. As rent-seeking is integral to party structures it is shaped by the close interaction of client groups with party cadres and party hierarchy. For the political patrons, supply to client groups is vital for their capacity to mobilise active contributors in political campaigns. For client groups, the election of their patron party to power is a collective good which secures regular access to rents, and to which they are highly incentivised to contribute.

These observations suggest that clientelism differs from the general image in the literature on interest group activity. It is thus reasonable to expect that due to its distinctive properties clientelism has different implications for the prospects of economic reform beyond what the general literature on rent-seeking has hitherto contended. Client groups, parties and the government cannot be portrayed as veto players autonomous from one another in terms of preferences and political behaviour. Instead, client groups and their patron parties are tied in relations of interdependency and have to act in coordination for mutual gain. Government autonomy to navigate itself across shifting alliances is expected to be considerably limited. Shifts in the allocation of rents must affect primarily relations inside the party and, ultimately, the cohesion and mobilisation capacity of each party. Hence, a systematic understanding of rent-seeking in a highly clientelist party system and of its impact on economic policy requires a focus on both intra-party and inter-party dynamics.

\section{Reform in a clientelist system: a party mobilization problem}

These distinct patterns of clientelist rent-seeking can be hypothesised from a rational choice perspective. Given that rent-seeking is integral to party organisations and both party leadership and cadres depend on their support in political campaigns, the capacity of client groups to influence policy may be substantially stronger. Within-party and between-party competition over clientelist demands will tend to create a strong incentive 
for the intensification of clientelism. It can be argued that clientelism introduces a systematic bias in economic policy in favour of preserving and expanding clientelist supply. The allocation of clientelist benefits can be depicted as the political equilibrium in a party system in which no party has an incentive to unilaterally reduce its commitments to client groups for fear that it will alienate its clients and undermine its mobilisation capacity. Limiting patronage will essentially open up a space for its opponent to step in and recruit from the party's clientele. Moreover, in the longer-run, as rent-seeking groups and political patrons exploit as much as possible the available rents, they ultimately deplete the country's fiscal resources. A 'tragedy-of-commons' situation can emerge sooner or later (C.f. Valesco 1994, 1998; Tornell 1995). This 'collectively irrational' outcome (the term used by Rodrik 1996:10) may take the form of a debt crisis, a balance-of-payment crisis or both.

By the same token, when pressing economic conditions bring forward the dilemma for the government party to choose between the launching of reforms and fiscal profligacy that caters for rent-seeking groups (Geddes 1994), the government in a clientelist party system may be less likely to push forward and act as a neutral arbiter among various distributive claims. Given its entrenched commitments to party clients, it will be difficult to reduce rent-seeking and abandon old allies or to build a new supporting coalition around a different constellation of interests as suggested by Geddes (1994), Heller, Keefer and McCubbins (1998) and Schamis (1999). The dominant strategy dictates that the party in government must avoid reforms that reduce the supply of clientelism unless this is urgent and inevitable. In that case, a reform package that significantly departs from the clientelist equilibrium is likely to undermine the cohesion of the party in government which relies on its ties with client groups. Such a move will also offer the opposition a powerful opportunity to orchestrate political action against the reform initiative. It is thus rational for the government to avoid or delay as much as possible any decision on reforms that will reduce the scope for political patronage such as privatisation and market liberalisation. When the government is under extreme pressure to implement a reform agenda, as long as the reforms mark a considerable shift away from the dominant strategy and reduce the scope for clientelism, the government will find itself in a politically suboptimal position.

These rational-choice predictions are testable hypotheses that require empirical confirmation. At an initial and rather explorative stage they can be traced and refined in the study of a case-study that is paradigmatic for the general class of phenomena (Eckstein 1975:80; Kuhn 1987; Flyvbjerg 2006), in our case, a highly clientelist economy that has undergone periods of economic crisis and rounds of policy reforms. This article examines Greece's first experience with far-reaching macroeconomic and structural reforms under the centre-right government of the New Democracy party led by Constantine Mitsotakis between 1990 and 1993. The scale and content of economic reforms implemented or under consideration by the Mitsotakis administration, as well as the timing of the reforms right after the spiralling of clientelist politics in Greece during the 1980s, make this period a suitable case-study for examining clientelism as a variable affecting the choice and fate of economic reforms in a highly clientelist economy.

By the mid-1980s, structural weaknesses and fiscal imbalances in Greece associated with extensive state ownership and continuous political interference in the economy had 
generated severe macroeconomic imbalances, declining competitiveness and rising unemployment. Between 1985 and 2000 consecutive Greek governments implemented reform programmes under pressing economic conditions. Throughout that period, the dominant presence of clientelist politics was widely regarded as a hindrance to the effective design and implementation of the reform agendas (Pagoulatos 2003; Pelagidis and Mitsopoulos 2006; Featherstone and Papadimitriou, 2008). This is hardly surprising knowing that clientelism and rent-seeking have been persistent features of Greece's political economy for decades. ${ }^{1}$ Greek governments acted systematically as 'collective patrons' (Sotiropoulos, 1994) to their active supporters most of which were appointed in the broader public sector and enjoyed a privileged status in terms of employment protection, wages, extra allowances and pension schemes. Promotions and access to crucial decision-making posts largely depended on associations with, and loyalty to the government party and its leading unionists and politicians.

It is, therefore, a key question to explore the degree to which these clientelist commitments shaped and obstructed reform agendas in Greece. To do so, it is essential to take into account the clientelist ties that connected decision-makers with the groups that resisted reforms, which part of the literature has regarded as 'veto-players' (Featherstone 2005, Mitsopoulos and Pelagidis 2011). The content and pace of the reforms implemented prior to Greece's entry to EMU varies by government and so do the linkages of each government with client groups in the broader public sector. PASOK had a dominant position among the employees of the broader public sector and their trade unions were controlled by leaders affiliated with the party. Some of the unionists later entered central politics as PASOL MPs and ministers. By contrast, New Democracy had a weaker political influence in the public sector but quite a few of its party cadres had close ties with the trade unions.

Moreover, the reforms implemented by Papandreou (1985-1989), Mitsotakis (19901993), Papandreou (1993-1996) and Simitis (1996-2000) differ considerably in terms of the policy mix each of them followed and, more significantly, in terms of the impact each of these reform programmes had on the supply of clientelist politics. The austerity programme of PASOK, Greece's socialist party, between 1985 and 1987 relied on taxation and incomes policy. Both measures diffused the cost of macroeconomic adjustment across the population leaving existing clientelist relations unscathed. Likewise, the last PASOK government under Andreas Papandreou (1993-1996) postponed privatisations to avoid the reaction of the party's base and mostly relied on direct taxes to balance public finances. A mixture of partial structural reforms and relatively strict fiscal policy was implemented by the Simitis government (1996-2000) in the run-up to EMU. Each of these reform programmes faced a different pattern of collective mobilisation, which can be associated with the content of the reforms implemented and the degree to which they affected embedded clientelist relations in the broader public sector.

By comparison, the economic policy of the Mitsotakis government was Greece's first encounter with a bold and extensive agenda designed to tackle the macroeconomic crisis that was simmering since the mid-1980s. The government openly advocated extensive privatisation and market liberalisation aiming at the reduction of the size and role of the state in the economy. This was a sharp departure from the political equilibrium 
in which Greece's two main political parties, New Democracy (ND) and PASOK, had been situated since 1975 during which they both followed policies of fiscal expansion and extensive state ownership that were largely catering for their political clienteles. The structural reforms announced by Mitsotakis were about to reduce the turf for clientelism for groups embedded in the broader public sector. Consequently, Mitsotakis' policies were seen as a threat to the status of privileged groups in the broader public sector that were closely linked to political parties, especially PASOK, and soon came under fire from both the opposition en bloc and segments of the New Democracy party. Reaction to reforms offered PASOK's ailing leader, Andreas Papandreou, the opportunity to restore the party's mobilisation capacity and image that had been previously tarnished by a series of economic scandals. In New Democracy a within-party rebellion undermined the party's cohesion and eventually brought down the government. The party suffered a landslide defeat in 1993, just three years after coming to power.

\section{Clientelism, crisis and Mitsotakis' liberal agenda}

New Democracy won the April 1990 election with 46.8\% of the popular vote and gained a narrow parliamentary majority of two MPs after two preceding elections held within a year in which it had failed to gain the absolute majority in the Parliament due to the highly proportional electoral law passed by the previous PASOK government. During the prolonged electoral period, PASOK had campaigned under the heavy shadow of several corruption cases. His leader, Andreas Papandreou was awaiting trial for his alleged involvement in a banking fraud scandal. Deserted by some of its former political allies and in poor health, Papandreou was facing increasing unrest among leading PASOK cadres over the prospects of the party under his leadership. Although he remained popular with the party base, Papandreou barely survived an informal vote of confidence when his favoured candidate for the post of party secretary was elected during a confrontational party meeting at the Pentelicon Hotel in November 1989.

Faced with deteriorating public finances and a stagnant economy, the new government launched an ambitious economic programme aiming at fiscal consolidation and structural reform. The reform proposals included the reduction of the size of the state through extensive privatisations, a significant degree of market liberalisation and cuts in the subsidies to ailing companies, agricultural cooperatives and pension funds. They also included the shutting down of ailing companies owned by the state in the event that their sale to private investors was not feasible, the reform of the terms of lending by stateowned banks in order to conform to private banking standards, the opening of areas of economic activity currently dominated by public utility companies to private entrepreneurship, managerial independence in the running of state enterprises, and greater

efficiency in the central administration. ${ }^{2}$ The declared agenda pledged to shift the country's economic paradigm away from the statist policies of the past fifteen years. Prime Minister Mitsotakis openly condemned 'the inconsiderate and unproductive expansion of the public sector' and explicitly expressed his liberal economic ideology:

'...There is proof around the world that the rules of the market guarantee better and cheaper products... Healthy competition is the best form of price control. I would say, the only form of control' (Praktika Voulis, $\Delta$ Session) 
Mitsotakis' rhetoric and policy agenda contradicted the long tradition in Greek politics of state intervention in the economy in the service of clientelist commitments. Market liberalisation and privatisation appeared to deny the party's own interest in securing and expanding its own clientelist base. This stance may be attributed to Mitsotakis' liberal ideological beliefs and the pressing economic conditions of the 1980s. Following his confrontational election to the party leadership in 1984 Mitsotakis openly proclaimed a liberal economic ideology for New Democracy. He remained a divisive figure within New Democracy for several years (Katsoudas, 1987), supported by the liberal segments of the New Democracy party but mostly tolerated rather than embraced by New Democracy's traditional voters and party cadres who regarded him, nonetheless, as the most suitable leader at the time to defeat Andreas Papandreou, the man who in 1981 had broken the right-wing monopoly of power in Greece since the 1960s. Mitsotakis's pragmatic political language contrasted with Papandreou's 'populist' style. The rhetoric in favour of market liberalisation and privatisation also resonated with the paradigmatic shift in Western Europe towards freer markets that was espoused by European institutions under the Single Market Programme. The political developments in Europe throughout the 80s were in sharp contrast to what was widely understood as failed economic policies in Greece (Verney 1993; Kazakos, 2001: Botsiou, 2002). Given New Democracy's ideological proximity to the idea of a freer market and its pro-European stance, it was easier for the party to adopt a political discourse that was critical of fiscal overspending, excessive state ownership and over-regulation. The same rhetoric was also strengthening the pro-European credentials of his party.

Moreover, by the late 1980s it had become clear that any elected government would have to take drastic measures to tackle Greece's soaring public debt, large budget deficits, high level of unemployment and declining competitiveness. As the clientelistic system was breaking down on its own weight, a call for a radical U-turn in economic policy was much more acceptable among voters and party members. There were, however, notable differences in the rhetoric and policy agenda between New Democracy and PASOK which can be associated with their different party bases. The discourse of market liberalisation fell on sympathetic ears among centre-right voters consisting of middle-class social strata, mostly small and medium-sized entrepreneurs, lawyers, doctors and other middle-class professional groups. The same agenda was threatening the privileged status of employees in the public sector where PASOK had a dominant political presence. In that respect, a liberal agenda by New Democracy appeared to be consistent with a rational party strategy to dismantle parts of the clientelist system dominated by PASOK. The reduction of the public sector through privatisation could in the long run reduce PASOK's hegemonic presence, which the party had secured thanks to its strong clientelist organisations in the broader public sector (kladikes).

\section{Initial asynchrony between stabilisation and structural reforms}

Government policy in the first two years fell short of the liberal rhetoric articulated by Mitsotakis and his key allies. Fiscal consolidation relied mostly on horizontal measures such as increases in taxation and a strict incomes policy in the public sector, and less on spending cuts and structural reforms (Bank of Greece 1992). Some progress was achieved in reducing the trade deficit, inflation and interest rates. ${ }^{3}$ There were, however, 
numerous policy inconsistencies. Increases in taxation to cover the government's shortfall in tax revenues had the unintended result of fuelling inflation which rose by three percentage points at the end of October 1991 (Bank of Greece 1992). Furthermore, while some restrictions were imposed on public sector wages, pensions and the welfare state, all other sources of public spending increased beyond what was predicted in the budget. Between 1990 and 1991, there was a 40.8\% increase in payments for public relations, a 34.0\% increase in travel expenditures for members of the armed and security forces and a $21.1 \%$ increase in special benefits and additional payments to permanent employees despite the general freeze in wages (Public Finance Statistics 1991:25). There was a considerable increase in the amount of funding to various ministries. ${ }^{4}$

By the end of 1991, the government was lagging behind on the front of social security reform, the reduction of public deficit and the fight against tax evasion. Despite Mitsotakis' liberal rhetoric, the government made little progress towards market liberalisation and privatisation. Its actual record in the first two years included the sale of peripheral loss-making companies and the tackling of their debts. The much larger public sector companies remained under state ownership. Initial plans to privatise the majority of the shares in the big state-owned companies proposed in September 1991 by the economically liberal minister of commerce, Andreas Andrianopoulos, were rejected. There were profound disagreements among prominent New Democracy politicians over the economic ideology of the government. On the one side, traditional centre-right politician and first minister of economy, Souflias, aired the opinion 'that the market should operate freely but there should be control over cases of excessive profits' (Nea, 25.08.1990, p.19) while, on the other side, Andreas Andrianopoulos, became openly critical of the government's performance:

'Neoliberalism means two things: reduction of the public sector on the one hand and reduction of taxation on the other. Here, we have had neither the one nor the other' (Nea, 25.08.1990, p.19).

Right from the start, New Democracy's fiscal policy met strong and coordinated reactions in the form of rounds of strikes and sizeable demonstrations from trade unions whose leadership was affiliated with PASOK. In the summer of 1990, they opposed the pay freeze in the public sector and the government's privatisation plans which they repeatedly described as scandalous 'sell-offs'.5 In September 1991 PASOK unionists raised maximalist claims for pay rises substantially above inflation and supported further strike action despite the reservations raised by New Democracy and left-wing unionists. A barrage of strikes followed: there were two 48-hour general strikes; cleaning workers left piles of garbage on the streets of Athens, industrial action in the electricity company caused periodic cuts of electricity supply, while strikes in public transport left Athens without a bus service for several weeks

\section{Privatisation, union mobilisation and PASOK}

The announcement of privatisation plans sent shockwaves to trade unions and employees in the public sector who responded with strikes and rallies. ${ }^{6}$ Prominent PASOK politicians openly endorsed the protests against privatisations. ${ }^{7}$ Reactions escalated with the closing down of Piraiki Patraiki, a deficit-running textiles company. Another 151 companies were scheduled to be sold or liquidated. The waves of strikes in public utility 
companies sent a clear message to the government not to proceed with its privatisation plans for the state monopolies in telecommunications, electricity, railways, airlines, post office and Greece's major banks.

As the first few sales increased uncertainty over the future of the larger state-owned companies and the employment status of their workforce, public statements by government officials did little to appease the anxiety among their employees. Minister of economy, Souflias, admitted that he could not predict the size of unemployment caused by privatisation but he could estimate the gain for the state at '510 billion at least' (Nea, May 1990, p.24). His successor, Christodoulou, described public companies as 'depositories for the unemployed' that had to be restructured (Nea, 13.12.1990, p.16). A broader ideological vision to sponsor the policy was missing from government rhetoric. The government advocated its privatisation programme primarily as a way to cut subsidies and raise revenue rather than a policy to liberalise markets and prices in order to improve competitiveness and improve services. ${ }^{8}$ The government rebranded privatisations as 'de-etatisations' (apokratikopoiiseis), a neologism invented to avoid any allusion that privatisation was a general sell-out. Not surprisingly, privatisation became a divisive issue among the public opinion. ${ }^{9}$ The government plan was also viewed with suspicion by part of New Democracy's rank-and-file with close ties with public sector unions.

The fiercest protest against a privatisation project took place in reaction to the dismantling of the Athens Bus Company in August 1992 leading to the dismissal of 8,000 employees. The rallies lasted for days and were openly supported by PASOK politicians. When the government offered the company employees preferential treatment in the purchase of individual buses under the new scheme, the union leaders associated with PASOK and the Communist Party rejected the proposal and organised rallies that eventually led to clashes on the streets of Athens. Following the escalating reactions from PASOK, the trade unions, and segments of the government party, further privatisation was halted and the agenda was largely compromised. While the actual sales had only affected a few thousand employees (Nea, 19. May 1990, p.25), New Democracy was experiencing considerable social unrest and a loss in popularity while failing to deliver on the ambitious reforms it had initially announced. Mitsotakis' uncompromising stance on privatisation and, in particular, in the case of the Athens Bus Company contributed to his increasingly unpopular image as an intransigent and overconfident leader. His shrinking circle of supporters was portrayed by the media as neoliberal zealots who preferred privatisation over any other effort to modernise public companies. ${ }^{10}$

The general backlash against government policy offered PASOK the opportunity to consolidate and reinvigorate its support basis in the broader public sector. PASOK vehemently opposed the government's fiscal policies. The 1991 budget was dubbed 'the harshest and most class-biased budget of the last decades'. ${ }^{11}$ The anti-austerity rhetoric allowed the party to distance itself from the bitter memories of its own strict programme a few years ago. PASOK spokesmen repeatedly rejected the privatisation of state-owned companies, and openly defended the status quo by propagating a strong role for the government in a wide area of economic activity: in 'natural' monopolies in sectors such as electricity and telecommunications, in monopolies and oligopolies in product and service markets that have 'a predominantly social character' such as public transport, in 
sectors of 'national-strategic importance' such as shipyards, in large industrial companies that can be used as 'tools for government industrial policy' such as the Greek cement industry (AGET) and the large textile company Piraiki-Patraiki, and, finally, in the banking system where 'banks under state control shall channel funds to particular investment projects' (Arsenis 1992; Also Nea 6.4.1993, p.11). These areas covered almost all the employment settings where PASOK had a dominant political presence.

By the end of 1991, the government was under attack on two fronts. On the political front, it was facing a general revolt orchestrated by PASOK and its trade unions with no signs of compromise from their part. Their joint activities were creating an atmosphere of general social unrest. ${ }^{12}$ Mitsotakis' intransigent stance on economic reforms was strengthening the symbiotic relationship between PASOK and the trade unions. In response, PASOK's vocal criticism of the government policy and the active endorsement of union actions helped the party restrain the influence of the Left parties, KKE and Synaspismos, in the labour movement. PASOK reconfirmed its dominant position in the trade unions by winning a clear majority in the General Union, GSEE, in March 1992.

On the front of the economy, results were poor and the government came under pressure to accelerate its effort for macroeconomic stabilization. The first stabilisation plan had limited success mostly by curbing government spending, raising state revenue, reducing tax evasion and restraining appointments in the public sector. The Commission's Report criticised the government for its economic policy between 1991 and 1992, in particular its inconsistent tax reform and the slow progress of privatisation. The Monetary Committee of the European Communities was also critical of government policy, reporting an actual increase in new appointments to the public sector by $1.2 \%$ contrary to the government pledges (Nea, 17.4.1992, p.16). In May 1992 the President of the Commission, Jacques Delors, talked of Greece's failure to follow the European course despite the support of the funds the country was receiving from the Community. Following two gloomy reports by OECD and IMF, former Prime Minister, Xenophon Zolotas, and leading economist, Angelos Angelopoulos, openly criticised the government for taking patchy and ineffective measures that had failed to reduce considerably the level of public spending. They both warned that the country was heading to bankruptcy. ${ }^{13}$ Even Andrianopoulos, Mitsotakis' liberal ally, called the first stabilisation programme an 'imitation' of the previous programme by PASOK between 1985 and 1987 only 'with a slant to other directions such as privatisation' (Economikos Tahydromos, 11.06.1992, p.5).

In response, Mitsotakis appointed an economically liberal politician, Stefanos Manos, as minister of the economy in February 1992 to accelerate the government's stabilisation effort. Manos admitted that there had been serious deviations from the declared economic targets and that the government had to start from a worse position. In March 1992, the government announced tax raises, further privatisations and the closing down of public companies. In response, the unions organised a new round of strikes in the broader public sector companies in telecommunications, electricity, post office, water and sewage, ports, railways, banks and the petrol industry. In December 1992, the government presented a new Convergence Programme (1993-1998) with tight monetary and fiscal targets and a strict incomes policy (Bank of Greece 1992:21). 
At the same time, increasing social unrest and poor economic results led to a sharp decline of New Democracy's popularity. By November 1991, New Democracy was lagging behind PASOK in opinion polls (Nea, 19.11.1991, p.12). Few months later, in April 1992, PASOK won a landslide victory in a by-election in Athens, the country's largest constituency, increasing its voting score by $30 \%$, or 100,000 votes. ${ }^{14}$ A triumphant Papandreou described the government as 'non-existent' and the country as 'ungoverned'. On an interview at a TV channel right after the electoral results, former Conservative Prime Minister Georgios Rallis proposed a broader coalition between ND and PASOK but the proposal was rejected by the two parties. Mitsotakis defended his economic policy before the parliament and pledged to keep to the convergence programme for another two years. He confronted mounting criticism from New Democracy's cadres and eventually had to call a vote of confidence, which he won. Throughout August and September 1992 strikes and rallies escalated in public transport, universities, the electricity monopoly, banks, gas stations, the post office, secondary education and farmers. Government officials were publicly booed by the crowd at the celebration in honour of the Greek Olympic medallists at the Panathinaicon Stadium on 11 August 1992.

\section{New Democracy's withering cohesion}

While PASOK was reinforcing its political position, internal divisions and criticism against Mitsotakis' policies were undermining the cohesion of New Democracy. The government was becoming increasingly alienated from traditional right-wing voters. The government's tax reform, for instance, triggered the reaction of doctors and lawyers. Lawyers went on a prolonged strike that lasted for 9 months with few in-between intervals. Inside New Democracy most reactions to Mitsotakis' economic policy came from the party faction known as the popular right (laiki dexia) with linkages to patronage politics and closely associated with the trade unions and the heavily subsidised agricultural cooperatives (Kazakos 1993:154). Prominent New Democracy politicians were supporting a greater role of the state and were opposed to the government's privatisation plans. ${ }^{15}$ They were also highly apprehensive of New Democracy's falling popularity among public sector employees, particularly in companies that were scheduled for privatisation. ${ }^{16}$

Privatisation turned out to the most divisive economic issue inside New Democracy. Strong reaction from segments of New Democracy associated with the state sector made it harder for the government to implement a bold policy agenda (C.f. Kazakos 2003). New Democracy's labour organisations actively joined the general protest against the government's privatisation plans. The tone of their reaction came to emulate PASOK's harsh language (Nea 11.12.1992, p.18). The privatisation plans for Olympic airways and the state monopolies in electricity, telecommunication and railways triggered clashes within the Cabinet - the most prominent between the liberal Andreas Andrianopoulos and Miltiadis Evert, a politician with the aspiration to becoming the next New Democracy leader, (Nea, 24.05.1990, p.17; and, 24.09.1991, p.2). Later on, Andrianopoulos, who had been appointed as the minister for commerce, openly announced that he had been the target of 'entrenched interests' in the trade unions and the management of the ailing state-

owned enterprises. ${ }^{17}$ Likewise, a number of managers in the broader public sector appointed by the government were not enthusiastic with the prospect of losing their posts 
once privatisation was completed. ${ }^{18}$ Several ministers were also unwilling to respond to Mitsotakis's request to submit lists of public enterprises for privatisation or closure (Economikos Tahydromos, 27.02.1992, p.3). The various delays and hurdles to the privatisation process caused the head of OAE, the organisation in charge of the ailing enterprises lined up to be privatised, to resign in protest for the frequent interference of government ministers in the privatisation programme:

'After working for more than a year I am certain that the ministers supervising the privatisation policy are the genuine children of statism, which is what brought them to prominence in the past, and that they cannot distance themselves from their old philosophy' (Economikos Tahydromos, 27.06.1991, p.16)

Tensions in the government party escalated as privatisations and austerity were limiting the available opportunities for clientelist exchange (Vima, 20.09.1992, p.8). New Democracy sympathisers and its grassroots organisations were putting pressure on the government to accommodate the demands of their political clientele which mostly involved appointments in the public sector (Vima 26.09.1991, p.26). Given the adverse state of public finances, party politicians had a limited scope to deliver favours ('rousfetia') to supporters except for costless concessions such as promotions and favourable placements (Vima 30.06.1991, p.27 and Nea, 18.03.1993, p.19) or the military (Kyriakatiki, 3.10.1993). As a result, New Democracy supporters were frequently complaining that PASOK was still the most powerful political force in the broader public sector.

Grievances and frictions concerning government policy and the privatisation process at times culminated in fierce resignations and allegations of corruption. In November 1992, minister of agriculture, Hatzigakis, resigned in disagreement with the government's decision to hire a private company to patrol forests for 'ideological, political, economic and moral grounds'. Few days later he stated that 'he would have been an accomplice to a crime had he signed the decision' (Vima 29.11.1992, p.1992). Similarly, former Minister of Health, Sourlas, talked of organised interests in pharmaceuticals that had pushed for his expulsion from the government (Nea, 04.12.1992, p.14). Allegations of corruption such as those ones regarding the management of ailing corporations and the privatisation process were widely reported in the press. ${ }^{19}$

Finally, business interests attached to the state sector and competing for preferential treatment became a major source of opposition to New Democracy's policy. Like any government in Greece, New Democracy had to address public sector contractors and suppliers whose political influence by the early 1990 had been strengthened through the ownership of private media (C.f. Papathanassopoulos 1999). The stakes for public sector contractors were higher than ever as Community funds were channelled to Greece while the privatisation programme was about to change drastically the terms of competition in the state sector. For state-sponsored businessmen, privatisation threatened to break their long-established links with public sector companies and their managers (Lyberaki and Tsakalotos 2002:108). Government spokesman, Magginas, openly referred to attempts by media owners to prevent the government from implementing its policy in the state monopolies of electricity and telecommunications: 
'The government policy hurts the interests of some known businessmen who have contracts with these state monopolies as well as the interests of some equally well-known partisan unionists' (Nea, 26.6.1993, p.11)

By 1992 Mitsotakis' policies had displeased some of the country's most powerful press barons (C.f. Pagoulatos 1994). The majority of private media, which a few years ago had revealed the scandals in which PASOK politicians including Papandreou himself had been allegedly involved, now switched to support PASOK. The public image of Papandreou, once presented by most of the press as an ailing politician presiding over a corrupt government, was restored. At the same time, a barrage of press releases was slashing government ministers, the Prime Minister and his family. Mitsotakis famously used the word 'diaplekomena' (entangled interests) to describe the collusion between state-sponsored businessmen and political power, a term which became emblematic in Greek politics:

'If the media get controlled by the big and entangled interest groups [diaplekomena]... this would mean the end of democracy in Greece... We [his government] were responsible, and we paid the related political cost. We had the courage not to compromise, and I am proud of that' (Praktika Voulis, Synod A, Session E, 24.10.1993)

\section{Culmination of protests and Mitsotakis' fall from power}

By the end of 1992, protracted austerity, poor economic results, divisions over privatisation and within-party reactions to specific policies had pushed the cohesion of New Democracy to its limits. Resignations from the Cabinet soon became frequent news in the media. Soon the group of dissenters grew. Some of them had supported Mitsotakis in his 1984 election to the party leadership and had been on the front line of the 19891990 electoral campaign. Deputy Prime Minister, Athanasios Canellopoulos publicly expressed his disapproval of the government's economic policy and said that the government measures were 'unjust and lacking imagination' (Vima, 9 January 1992). Canellopoulos resigned from the government a few days later accusing the PM for his refusal to discuss economic policy with cabinet ministers. He was joined by former minister Miltiadis Evert on 11 February 1992. Later on, in a parliamentary speech Evert blamed the government for following a policy that was shrinking the economy and causing stagflation (Nea, 18.3.1992, p.14). As New Democracy's parliamentary majority relied on two MP seats, it was impossible for Mitsotakis to punish the dissenters with expulsion from the party, for the reason that this move could bring his government down. Inside the party, the opposition was formed around two aspiring leaders of New Democracy, on the one side, Antonis Samaras, former minister of foreign affairs who Mitsotakis had ousted from the Cabinet for his disagreement over foreign policy on the Macedonian name dispute, and on the other side, former minister Evert surrounded by Kanellopoulos and former minister Dimas. The three men jointly submitted a memorandum to the prime minister asking for the postponement of the proposed economic measures that, in their view, had led to economic recession and were socially unjust. Antonis Samaras eventually resigned as an MP on 21 October 1992, attacking the policy of 'hard drachma' and the government's obsession with reducing the deficit (the 
'deficit-mania' as he called it) on several occasions (Nea, 4 and 10 December 1992). A new round of confrontations within the party erupted when the 1993 budget announced the partial privatisation of OTE, Greece's telecommunication monopoly, within that year. The planned privatisation of OTE turned out to be the most divisive issue for the government party. ${ }^{20} \mathrm{New}$ Democracy's trade unionists and politicians openly voiced their objections. A number of ND MPs stated that they might vote against the budget.

The privatisation of OTE was seen by trade unions as a forerunner to a new round of privatisations, this time involving the large public utilities companies in electricity, railways, airlines, water, oil refineries, post office and the banks. To avoid further reactions Stefanos Manos pledged that the electricity company would remain under exclusive state ownership. ${ }^{21}$ That reassurance hardly appeased the reactions. In the summer of 1993 trade unions whose leaderships were affiliated to PASOK organised a new round of strikes and rallies which created an explosive social atmosphere. ${ }^{22}$ GENOPDEI, the trade union in the electricity company, dubbed the privatisation process 'the Prime Minister's robbery plans' that were 'paving the way for a raid by foreign capital and the prime minister's company at the expense of national wealth' (Nea, 24.07.1993, p.7). Papandreou himself visited the headquarters of OTE and, cheered by unionists and employees, he openly pledged to cancel the privatisation upon his return to power (Nea, 05.05.1993, p.5).

Reactions inside the party escalated in the summer of 1993. Both former ministers Samaras, who had founded a new party, Political Spring, and Evert, who stayed in New Democracy, openly expressed their objections to the OTE plan. ${ }^{23}$ Evert announced his decision to vote against the privatisation unless there were guarantees concerning the transparency of the process and the government was to retain control over key firm decisions (Nea 16.7.1993, p.8). In a letter to the government and the party, New Democracy's unionists of OTE warned the government that they were on the point of a final break with the party (Nea, 15.7.1993, p.8). In September 1993 Antonis Samaras and his allies in the New Democracy withdrew their vote of confidence in the government in protest against the handling of the Macedonian name dispute. A month after the government had officially announced the partial privatisation of OTE, the sale was aborted and a fierce electoral period began. Mitsotakis openly talked of business circles orchestrating his fall from power and preparing for the return of PASOK to government. In similar vein, the right-wing press talked of entrepreneurs with vested interests in the state monopolies in electricity and telecommunications whose media were openly supporting PASOK's campaign (C.f. Typos tis Kyriakis, 3.10.1993).

PASOK's campaign in the 1993 election was attacking New Democracy's policies as ineffective, authoritarian and socially unjust. It named New Democracy 'the party of bankruptcy' that had failed to boost the economy despite the harsh measures it had imposed on society. ${ }^{24}$ PASOK's message conveyed a clear disapproval of privatisations that were repeatedly named 'sell-offs of national property' and reiterated its preference for a strong and protective welfare and interventionist state. ${ }^{25}$ PASOK's campaign and previous record in the opposition cultivated expectations among its support groups in the public sector that it would cancel the privatisation programme when in government. PASOK's economic policy proposals were vague, placing emphasis on raising the 
productivity of the Greek economy instead of following austerity policies, and emphasising the need for social dialogue and 'new forms of social solidarity':26

'At last, this is the end; the neoliberal parenthesis is shut down for good. We are putting an end to the austerity policy, the high prices, the unemployment, the selling-off of national wealth, the inequalities and authoritarianism [of the government]. The right to hope is rising again' (Greece is the vision, PASOK's campaign leaflet).

From a defensive position, New Democracy criticised PASOK's stance as obsolete and perilous for the economy. ${ }^{27} \mathrm{New}$ Democracy's 1993 campaign presented voters with the dilemma between reforms and rising levels of taxation, ${ }^{28}$ and pointed out the contrast between 'fiscal responsibility' exhibited by New Democracy and PASOK's past record of 'profligate and statist politics':

'What is that PASOK desires: Power; without any concern about Greece; a large public sector, because a large public sector means a large scope for favours. It [PASOK] intends to surrender the [public] organisations to its party members and its trade unionists. It wants to cancel the privatisation (apokratikopoiisi) because some people will lose control over procurements... There was [once] the easy way: Endless promises, vote-buying, concessions, favours, appointments; the road PASOK knows very well. We have not followed it. We have chosen to stay uncompromisingly consistent with our positions, our values, our ideas... We have not been afraid of political cost.' (New Democracy's leaflet 'Greece is not turning back). ${ }^{29}$

The dramatic events that led to the fall of the New Democracy government helped the party restore some of its cohesion in the month before the October election. In an effort to cheer New Democracy's supporters, government officials promised to relax economic policy if re-elected. ${ }^{30}$ The party's campaign was also tainted with accusations that a number of New Democracy supporters had been hired to posts in public sector enterprises during the electoral period. This late call-to-arms by New Democracy failed to block PASOK's march to power. With a coherent and active party base and the support of most of the private media, PASOK won the election with approximately $46 \%$ of the vote. The night of the election, Mitsotakis resigned as leader of New Democracy and a few days later the vast majority of the party's MPs elected Evert in his place.

\section{The Mitsotakis period assessed: actions, reactions and collective action}

Faced with the general rebellion led by trade unions, the opposition and within-party factions and despite New Democracy's weak parliamentary majority by two seats, the Mitsotakis government implemented important reforms, most notably the privatisation or liquidation of around 100 enterprises, the abolition of most price controls and the partial liberalisation of labour, house rents, fuel and credit. Whether dictated by the urgency of the economic condition, ideological conviction or both, Mitsotakis' attempt to implement a bold and extensive reform agenda to reduce the size of the state proved to be a politically suboptimal decision. Economic policy and, for the most part, the privatisation programme moved the government party away from the clientelist equilibrium, 
unleashing the reaction of interest groups that had been settled in the old status quo. Structural reform and privatisation threatened the status of client groups in the broader public sector with strong organisation capacity and ties to the political parties. It also threatened the position of state-dependent businessmen that were pushing for preferential treatment in their deals with public sector companies. As Mitsotakis noted:

'Privatisation between 1990 an 1993 proceeded amidst a climate of corruption of employees (the case of Pirelli), sit-ins in factories and on national roads, attacks on foreign investors, letters by Mr. Papandreou (OTE) and Tsohatzopoulos threatening prospective buyers (shipyards); it is a miracle in that climate of hatred and negation buyers were found and contracts were signed, which, to say the least, spared the government budget tens of billions of damages in the last two years' (Mitsotakis in Economikos Tahydromos, 31.08.1995, p.22).

Collective action against the reforms as well as the prolonged economic austerity generated a period of social unrest with two politically significant effects: PASOK, by orchestrated a general sabotage of the government policies thanks to its permanent ties with the unions and with an opportunistic alliance with private media and capitalised upon growing public dissatisfaction and the weakness of the Mitsotakis government to sell the reforms to the public opinion. By placing the interests of groups attached to the public sector under its sponsorship PASOK rebuilt its remarkable capacity to mobilise and coordinate its grassroots organisations. On the opposite site, New Democracy became alienated from key supporters mainly in the public sector. While the party's official ideology was propagating a smaller state, large segments of the New Democracy's base stood up to oppose actual policy decisions limiting appointments in the public sector, dismissing employees, and privatising companies, which all reduced the turf for political patronage. In essence, Mitsotakis presided over a party and a political system imbued with a statist economic ideology and eroded by clientelism. (Economikos Tahydromos, 11.06 .1992$, p.4). The policy was largely discredited by its own party cadres and at the end some of them placed a veto (Economikos Tahydromos, 27.02.1992, p.3). Ever since his electoral defeat in 1993, Mitsotakis remained bitter about the resistance his policies met.

'In privatisation, in market liberalisation, in the reform of social security, in education and welfare policies we faced harsh backlash everywhere, while political interest groups rushed to take advantage of the political cost my government was obliged to carry on its shoulders (Praktika Voulis, Synod A, Session E, 24.10.1993).

\section{Concluding remarks: Reforms and political mobilization}

The political fate of the Mitsotakis reform agenda is additional evidence that reforms trigger the reaction of groups expecting direct and severe losses and that they fail to mobilise enough support for the reason that the anticipated fiscal and economic benefits at the stages of decision and implementation are too dispersed and uncertain. The pattern observed in the Mitsotakis' period is also a refinement of this general hypothesis indicating that collective action in a highly clientelist political economy has distinct implications for party politics because of the position of the affected groups in the party 
system. Clientelism describes the incorporation of rent-seeking into party structures and the political integration, or even merging, of rent-seeking groups with the party system. Client groups differ from typical rent-seeking groups in terms of autonomy from, bargaining power against, proximity to, and importance for the political parties. Consequently, clientelist parties must continue to deliver selective benefits to their clientele such as better terms of employment, generous benefits and pension schemes even in conditions of economic crisis in order to incentivise their active support which is essential for their political campaign. Political parties are, therefore, locked in a political equilibrium that tends to be collectively irrational from an economic point of view as a crisis approaches and later escalates. Measures to tackle this crisis, however, are politically suboptimal to the extent that they disturb existing clientelist commitments. In short, resistance to policy reform comes from within the structure of the clientelist party.

In real-world settings, governments often implement sweeping reforms for many reasons, such as ideology, economic shocks, pressures from international institutions and the urgency of the crisis. Strategic miscalculations or ideological predispositions may lead a government to implement a reform agenda with characteristics that run contrary to the dominant strategy favouring keeping clientelism intact. When such reforms are launched, they are likely to trigger the reaction of client groups attached either to the government party or to the opposition party. Collective action takes the form of defensive mobilisation against the reforms and could change the relative mobilisation capacity of the political parties. Policies that pose limits to the supply of clientelism offer the leadership of the opposition the opportunity to restore and strengthen the unity of the party by strategically standing up to defend the interests of its client groups. The opposition party can renew its clientelist ties and can eventually profit in the next election from the collective action of the client groups taking place under its auspices. The same policy mix can undermine the cohesion of the government party by alienating client groups in the sectors hurt by reform and can offer grounds for the internal opposition to appeal to discontented party supporters. At the end, the party leadership may suffer from frictions and tensions inside the party that potentially lead to factionalism and defections. As unity falls apart, the party's chances of winning the next election are diminishing.

\section{Notes}

1. Among the most prominent works on clientelism in Greece: Mouzelis, 1978; Lyrintzis, 1984; Mavrogordatos, 1984; Spourdalakis 1988; Sotiropoulos, 1994 and 2001; Tsoukalis 1997; Pappas, 1999; Lyberaki and Tsakalotos, 2002; Pagoulatos 2003; Lavdas, 2005.

2. Programmatic declarations of Prime Minister Mitsotakis on 24.4.1990 in the Greek Parliament, Praktika Voulis, $\Delta$ Session, pp.18-19.

3. See interview by Henning Christophersen, Vice President of the EC Commission in charge of supervising Greece's stabilisation programme at Nea, 24 February 1992. p.12

4. Funds allocated to the ministry of merchant shipping increased by $1,000 \%$ between 1989 and 1990 , to the ministry of foreign affairs by more than $700 \%$ between 1990 and 1991, to the ministry of labour by over $300 \%$ between 1990 and 1991, and to the ministry of public order by around $100 \%$ between 1990 and 1991. There was a sizeable increase in the expenses of the ministries of Aegean Sea (from 630.7 to 1,215 million drachmas) and Northern Greece (from from 366.0 million drachmas to 1,546.8 million drachmas) between 1988 and 1989 (source: Public Finance Statistics, 1991). 
5. For instance: Nea, 30.12.1991; 13.03.1992; 07.04.1993, p.10; 06.04.1993, p.10; 07.07.1993, p.16' 16.07.1993, p.8; 17.07.1993; 14; 26.07.1993, p.10; 12.08.1993, p.12. Also Vima 01.03.1992, p.12;

6. As documented in Nea, 25.05.1990, p.14; 08.11.1990, p.11; 01.11.1990, p.12; 23.02.1991, p.16; , 14.03.1991, p.12; 20.03.1991, p.11; 21.03.1991, p.10' 18.10.1993, p.12.

7. Nea, 28.05.1990, p.22; 31.08.1990, p.16; 28.11.1990, p.10-11; 21.02.1991, p.36; 26.02.1991, p.9; 15.03.1991, p.26; 07.07.1993, p.16.

8. C.f. Nea, 23.3.1990, p.2. Minister of the economy, Manos, suggested that an increase in the price of telecommunication charges would raise the revenue the government could achieve by privatising the company (Economikos Tahydromos, 3.12.1992, p.4). See also; Economikos, 15.10.1992, p.43, and 26.12.1991, p.33.

9. $42.2 \%$ of respondents to a survey by Nea $(19.11 .1991, \mathrm{p} .12)$ were in favour of privatisation and 46.9\% were against. $50.3 \%$ of respondents to the MRB Opinion poll (Kathimerini 17.7.1993) held the view that privatisations 'serve the interest of particular big business interest and they do not constitute an effort to make their operation more effective in the general interest of the economy'.

10. Nea on the 'sell-off 'of OTE, 19.11.1992, p.13; and Economikos Tahydromos, 22 July 1993, p.15.

11. Former PASOK minister Arsenis discussing the budget, Nea 04.12.1990, p.12.

12. When Greece's general union, GSEE, signed an agreement with the industrialist's organisation (SEV) for wage increases around $12.5 \%$ and $10.6 \%$ for the following two consecutive years (5 March 1991), PASOK's Executive Bureau openly reprimanded Labros Kanellopoulos, head of GSEE, for his signature.

13. Nea 25 July 1992, p.16. Also; Interview of Angelopoulos, Nea, 23.09.1993, p.10.

14. New Democracy did not take part in that election.

15. As noted by Economikos Tahydromos 22.7.1993, p.15; 1/05.1997, p.32. See also: Nea, 22.05.1990 p.24; 05.04.1991, p.20. Miranda Xafa, economic advisor to Mitsotakis at the time, admitted in an interview few years later that although there had been favourable economic conditions for the implementation of such a radical programme in the beginning, there had been multiple political reactions, some of the strongest coming from within the New Democracy: Economikos Tahydromos, 1 May 1997, p.32.

16. For instance, there was a dramatic fall of $16.56 \%$ in the votes cast for New Democracy's candidates in the trade union in the National Bank of Greece/Mortgage and the Industrial Development Bank (ETBA) against a 11.6\% rise for PASOK's candidates (Nea, 26.05.1993, p.17).

17. Andrianopoulos sent a letter to the Prime Minister (Vima, 28.06.1992, p.10).

18. Economikos Tahydromos 06.09.1990, p.78-79; 27.02.1992, p.4; and 11.12.1992, p.18.

19. C.f. Economikos Tahydromos, referring to auditing control and prosecutions, 15.08.1991, p.79.

20. Nea, 08.07.1993, p.6; 08.04.1993, p.6; 12.07.1993, p.8; and 24.07.1993, p.7.

21. Economikos Tahydromos, 05.08 .1993 , p.4.

22. Nea, 26.05.1993, p.17; and 12.08.1993, p.9.

23. Nea 28.7.1993, p.11;

24. C.f. PASOK's leaflet 'Enough is enough: there is another solution', which criticised New Democracy's policies for producing unemployment, closures, a dramatic reduction of incomes, an increase of social inequalities, the 'commercialisation' of the health system and the 'selling-out' of national property, with direct references to public enterprises in telecommunications, electricity, manufacturing, shipyards and public transport.

25. See, for instance, PASOK's leaflet for young voters, 'Today we turn the page: 1990-1993': 'We were appalled by the selling-off or our national property... We are asking for subsidies for new job posts, educational seminars for the young, incentives and support for new professionals and scientists, subsidies to new couples for accommodation, support and protection of the newly employed, a stable meritocratic system of appointments to the public sector, priority in employment for people with special needs... We demand the permanent closure of the private para-universities'.

26. 'Greece is the Vision', PASOK's campaign leaflet.

27. 'We are in the position to ascertain that the austerity is going to end' said Mitsotakis in an interview in Eleftherotypia, 3.10.1993. Minister of internal affairs, Kouvelas, stated in another interview:

'Whenever they [PASOK] exerted criticism, they asked us to follow their practices from the 80s. It [PASOK] is against privatisations, they have always wanted the giant-state. They try to portray the protagonists of scandals as heroes. We have not seen a new programme. What its members are 
proposing is incoherent and contradictory... Their ideology remains the same: Third World socialism' (Eleftheros Typos, 5.10.1993).

28 Interview by minister of internal affairs, Sotiris Kouvelas to Andreas Zoulas, Apogevmatini, 1.10.1993.

29. A quote from the New Democracy's electoral leaflet, ' $5+5$ facts you cannot dispute': "We have to decide for the future of the country, the future of our children. Between a strong Greece and an overindebted Greece which is obliged to 'beg' for borrowed money. We have laid the foundations. At a time of uncertainty and tension, our country is safe, secure and peaceful. Now that it takes strength and responsibility, should we trust Greece to Mr. Papandreou? Shall we risk it?',

30. C.f. 'Generous increases for the public employees', interview by minister of internal affairs Kouvelas to Andreas Zoulas, Apogevmatini, 1.10.1993; also Makedonia, 6.9.1993.

\section{References}

Alesina Alberto and Allan Drazen (1991). “Why Are Stabilizations Delayed?”, American Economic Review, 81:5, 1170-1199.

Arsenis, Gerasimos (1992). "Contribution to the Discussion among Political Agents", in Yannis Tolios (ed.), Progressive Modernisation: A Response to the Privatisation Policy (in Greek). Athens: Economic Policy Council, 21-29.

Bank of Greece (1992). Annual Report of the Governor for the Year 1991. Athens: Bank of Greece.

Becker, Gary (1983) "A Theory of Competition among Pressure Groups for Political Influence”, Quarterly Journal of Economics, 98:3, 371-400.

Becker Gary (1985) "Public Policies, Pressure Groups and Dead Weight Costs", Journal of Public Economics 28:3, 329-347.

Botsiou Konstantina E. (2002). "Greece in the EU: A Historical Account", in Panayotis C. Ioakimidis (ed.), Greece in the EU: The New Role and the New Agenda. Athens and Brussels: EKEM/Greek Ministry of Press/European Commission, 17-36.

Buchanan James M., Tollisson Robert D., and Tullock Gordon, eds. (1980). Towards a Theory of the Rent-Seeking Society. College Station: Texas A \& M Press.

Callaghy, Thomas M. (1990) "Lost Between State and Market: The Politics of Economic Adjustment in Ghana, Zambia and Nigeria", in Nelson, Joan M. (ed.), Economic Crisis and Policy Choice: The Politics of Adjustment in the Third World. Princeton NJ: Princeton University Press, 257-319.

Chubb, Judith (1982). Patronage, Power and Poverty in Southern Italy: A Tale of Two Cities. Cambridge: Cambridge University Press.

Eckstein, Harry H. (1975) "Case Study and Theory in Political Science", in F. J. Greenstein \& N. W. Polsby (eds.), Handbook of Political Science. Reading, MA: Addison-Wesley, 79-137.

Evans, Peter (1992). "The State as Problem and Solution: Predation, Embedded Autonomy, and Structural Change", in Stephan Haggardand Robert R. Kaufman (eds.), International Constraints, Distributive Conflicts and the State. Princeton NJ: Princeton University Press, 139-181. 
Featherstone, Kevin (2005) 'Introduction: 'Modernisation' and the Structural Constraints of Greek Politics', West European Politics 28:2, 223-241.

Featherstone, Kevin and Dimitris Papadimitriou (2008). The Limits of Europeanization: Reform Capacity and Policy Conflict in Greece. London: Palgrave Macmillan.

Flyvbjerg, Bent (2006). "Five Misunderstandings About Case-Study Research", Qualitative Inquiry 12:2, 219-245.

Geddes, Barbara (1994). Politician's Dilemma: Building State Capacity in Latin America. Berkeley CA: University of California Press.

Haggard, Stephan (2000). "Interests, Institutions, and Policy Reform", in Anne O. Krueger (ed.), Economic Policy Reform: The Second Stage. Chicago and London: University of Chicago Press, 21-59.

Haggard, Stephen, Richard N. Cooper and Chung-in Moon (1993). "Policy Reform in Korea", in Robert H. Bates, and Anne O. Krueger (eds.), Political and Economic Interactions in Economic Policy Reform: Evidence from Eight Countries. Oxford and Cambridge MA: Blackwell, 294-332.

Heller, William B., Philip Keefer and Mathew McCubbins (1998). "Political Structure and Economic Liberalization: Conditions and Cases from the Developing World", in Paul W. Drake and Mathew D. McCubbins (eds.), The Origins of Liberty: Political and Economic Liberalization in the Modern World. Princeton NJ: Princeton University Press, 146-178.

Katsoudas, Dimitrios, K. (1987). "The Conservative Movement and New Democracy: From Past to Present", in Kevin Featherstone and Dimitrios K. Katsoudas (eds), Political Change in Greece: Before and After the Colonels. London and Sydney: Croom Helm, 85-111.

Kazakos, Panos (1993) "The Regulatory Role of the State in the Economy: Problems and Prospects of Privatisation Policy in Greece", in Loukas Tsoukalis (ed.), Greece in the European Community: The Challenge of Adjustment (in Greek), Athens: EKEM, 129171.

Kazakos, Panos (2003) "Greece: Stabilization and Reform in the 90s", in P.C. Ioakimidis (ed.), Greece in the European Union: The New Role and the New Agenda. Athens: Ministry of Press and Mass Media, 133-155.

Krueger, Anne O. (1974). "The Political Economy of the Rent-Seeking Society", American Economic Review 64:3, 291-303.

Kuhn, Thomas S. (1987) "What Are Scientific Revolutions?”, in Lorenz Krüger, Lorraine J. Daston, and Michael Heidelberger (eds.), The Probabilistic Revolution, Vol. 1: Ideas in History. Cambridge, MA: MIT Press, 7-22.

Lavdas, Kostas A. (2005): "Interest Groups in Disjointed Corporatism: Social Dialogue in Greece and European 'Competitive Corporatism", West European Politics, 28:2, 297-316. 
Lyberaki, Antigone and Tsakalotos, Euclid (2002). "Reforming the Economy Without Society: Social and Institutional Constraints to Economic Reform in Post-1974 Greece", New Political Economy 7:1, 93-114.

Lyrintzis, Christos (1984). "Political Parties in Post-junta Greece: A Case of "Bureaucratic Clientelism"?", in Geoffrey Pridham (ed.), The New Mediterranean Democracies. London: Frank Cass, 99-118.

Mayhew, David. R. (1986). Placing Parties in American Politics Organization, Electoral Settings, and Government Activity in the Twentieth Century. Princeton NJ: Princeton University Press.

Mavrogordatos Giorgos (1984). "The Greek Party System: A Case of Limited but Polarized Pluralism?", West European Politics 7:4, 156-69.

Mitsopoulos Michael and Theodore Pelagidis, 2011, Understanding the Crisis in Greece: From Boom to Bust, Basingstoke: McMillan Palgrave.

Mouzelis, Nicos (1978). Greece: Facets of Underdevelopment. London: Macmillan and Holmes \& Meier.

National Statistical Service of Greece (1993) Public Finance Statistics 1991, Athens: National Statistical Service.

Olson, Mancur (1971/1965). The Logic of Collective Action: Public Goods and the Theory of Groups (Revised edition ed.). Cambridge MA: Harvard University Press.

Pappas, Takis S. (1999). Making Party Democracy in Greece. London: Macmillan.

Pagoulatos George (1994). The Press and the Politics of State Withdrawal in Greece (1990-1993): From Knee-jerk Reaction to Agenda-Setting Opposition. London: Mimo.

Pagoulatos George (2003). Greece's New Political Economy: State, Finance and Growth from Postwar to EMU. Basingstoke: Palgrave Macmillan.

Papathanassopoulos, Stylianos (1999) "The Effects of Media Commercialization on

Journalism and Politics in Greece", The Communication Review 3:4, 379-402.

Rodrik, Dani (1996). "Understanding Economic Policy Reform", Journal of Economic Literature 34:1, 9-41.

Schamis Hector E. (1999). "Distributional Coalitions and the Politics of Economic Reform in Latin America", World Politics 51:2, 236-268.

Sotiropoulos, Dimitri (2001). The Peak of the Clientelist State: Organization, Personnel and Politicization of the High Echelons of the Greek Public Administration, 19742000 (in Greek). Athens: Potamos.

Sotiropoulos, Dimitri, A. (1994). "Bureaucrats and Politicians: A Case Study of the Determinants of Perceptions of Conflict and Patronage in the Greek Bureaucracy under PASOK Rule, 1981-1989”, The British Journal of Sociology, 45:3, 349-365.

Spourdalakis, Michalis (1988). The Rise of the Greek Socialist Party. London: Routledge. 
Stigler, George, J. (1971). "The Theory of Economic Regulation", The Bell Journal of Economics and Management Sciences 2:1, 3-21.

Tornell Aaron (1995). “Are Economic Crises Necessary for Trade Liberalization and Fiscal Reform? The Mexican Experience", in Rudiger Dornbusch and Sebastian Edwards (eds), Reform, Recovery, and Growth: Latin America and the Middle East. Chicago: University of Chicago Press, 53-73.

Tsoukalis, Loukas (1997). "Beyond the Greek Paradox", In Graham Allison and Kalypso Nicolaidis (eds.), The Greek Paradox: Promise vs. Performance. Cambridge MA: John F. Kennedy School of Government, Center for Science and International Affairs, 163-174.

Tullock, Gordon (1993). Rent-Seeking. Aldershot: Edward Elgar.

Tullock, Gordon (2005). The Rent-Seeking Society: The Selected Works of Gordon Tullock, Vol.5. Indianapolis: Liberty Fund.

Velasco, Andrés (1998). "The Common Property Approach to the Political Economy of Fiscal Policy", in Federico Sturzenegger and Mariano Tommasi (eds.), The Political Economy of Reform. Cambridge MA and London: MIT Press, pp.165-184.

Verney, Susannah (1993). 'From the 'Special Relationship' to Europeanism: PASOK and the European Community, 1981-89”, in Richard Clogg (ed.), Greece, 1981-89: The Populist Decade: Hampshire and London: Macmillan, 131-153.

Ware, Alan (1992). "Activist-Leader Relations and the Structure of Political Parties: Exchange Models and Vote-seeking Behaviour in Parties", British Journal of Political Science 22:1, 71-92.

Ware, Alan (1996). Political Parties and Party Systems. Oxford and New York, Oxford University Press.

Waterbury, John (1992). "The Heart of the Matter? Public Enterprise and the Adjustment Process", in Stephan Haggard and Robert R. Kaufman (eds.), International Constraints, Distributive Conflicts and the State. Princeton NJ: Princeton University Press, 182-217.

Zuckerman, Alan (1979). The Politics of Faction: Christian Democratic Rule in Italy. New Haven CN.: Yale University Press. 